http://jurnaltarbiyah.uinsu.ac.id/index.php/raudhah

e-mail: jurnalraudhah@uinsu.ac.id

p-ISSN: 2338-2163

e-ISSN: $2716-2435$

\title{
Etika Pergaulan Keluarga Muslim Sebagai Pembetukan Karakter Anak
}

\author{
H. As'ad \\ UIN Sumatera Utara \\ email: as’ad@uinsu.ac.id
}

Article received : 17 Agustus 2021
Article accepted : 15 Oktober 2021

Review process : 23 September 2021

Article published : 01 Desember 2021

\begin{abstract}
Abstrak
Sebuah Keluarga yang bertanggung jawab terdiri dari suami dan istri atau ayah dan ibu dan anak-anak adalah unit terkecil dari suatu masyarakat. hubungan yang terjadi dalam sebuah keluarga akan harmonis, aman, tentram, sejuk dan nyaman, penuh cinta kasih, sehingga keluarga mendapat informasi dan kebahagiaan. Karakter merupakan nilai-nilai perilaku dari manusia yang berhubungan dengan Tuhan yang Maha Esa, diri sendiri, sesama makhluk ciptaan manusia (manusia, hewan, tumbuhan), dan nilai kebangsaan yang tewujud dalam pikiran, sikap, perasaan, perkataan serta perbuatan berdasarkan norma-norma agama, hukum, tata krama, budaya, dan adat istiadat. Pendidikan karakter merupakan suatu sitem yang berfungsi untuk menanamkan nilai-nilai karakter kepada anak yang meliputi komponen pengetahuan, kesadaran dan kemauan, serta tindakan untuk melaksanakan nilai-nilai tersebut, baik terhadap Tuhan yang Maha Esa, diri sendiri, sesama manusia, seluruh makhluk ciptaan Allah, lingkungan, maupun kebangsaan sehingga menjadi manusia insan kamil. Metode dan jenis pengumpulan data dalam penelitian ini adalah studi kepustakaan. Proses penelitian dimulai dengan tahapan sebagai berikut: Menemukan dan menemukan informasi yang relevan dengan tema penjaminan mutu, kemudian menganalisis temuan dan kemudian mengembangkan dan mengungkapkan temuan baru terkait etika sosial dalam keluarga sebagai pembentukan karakter anak.
\end{abstract}

Kata kunci: Sikap, Keluarga Muslim, karakter, anak

\begin{abstract}
A responsible family consisting of husband and wife or father and mother and children is the smallest unit of a society. relationships that occur in a family will be harmonious, safe, peaceful, cool and comfortable, full of love, so that the family gets information and happiness. Character is the behavioral values of humans related to God Almighty, oneself, fellow human creatures (humans, animals, plants), and national values that are manifested in thoughts, attitudes, feelings, words and actions based on norms. religion, law, manners, culture, and customs. Character education is a system that functions to instill character values in children which includes components of knowledge, awareness and willingness, as well as actions to implement these values, both towards God Almighty, oneself, fellow humans, all of God's creatures. , environment, and nationality so that they become human beings. The method and type of data collection in this research is literature study. The research process begins with the following stages: Finding and finding information relevant to the theme of quality assurance, then analyzing the findings and then developing and revealing new findings related to social ethics in the family as the formation of children's character.
\end{abstract}

Keywords: Attitude, Muslim family, character, children 
http://jurnaltarbiyah.uinsu.ac.id/index.php/raudhah

e-mail: jurnalraudhah@uinsu.ac.id

p-ISSN: 2338-2163

e-ISSN: 2716-2435

\section{A. PENDAHULUAN}

Dalam kata bahasa Arab keluarga dapat diartikan dari kata, (ahlun dan usrah). Menurut Ahmad Musthafa al-Maragi, Tafsir al-Maraghi, 1974 : 162. Keluarga ialah terdiri dari ayah dan ibu, anak dan hamba sahaya seisi keluarga. Senada dengan itu pula, Hammudah 'Abdu al-A'ti, mengatakan keluarga terdiri dari seorang laki-laki sebagai suami, istri dan hubungan keluarga keatas yaitu ayah, kakek, nenek, dan seterusnya, atau kebawah yaitu anak, cucu dan cicit seterusnya. Sedangkan menurut M. Quraish Shihab, membumikan Al-Qur'an 1984 : 255. Keluarga yaitu umat terkecil yang memiliki pimpinan dan anggota, mempunyai pembagian tugas dan kerja, serta hak dan kewajiban bagi masing-masing anggotanya.

Dari beberapa definisi diatas dapat dipahami bahwa, keluarga adalah masyarakat terkecil yang meliputi adanya ayah dan ibu serta keturunan dari keduanya yang mempunyai tugas dan kewajiban serta hak mereka masing-masing. Sebuah keluarga yang bertanggung jawab, terdiri dari suami istri atau ayah dan ibu serta anak-anaknya merupakan unit terkecil dari suatu masyarakat. Di dalamnya sudah menjadi keharusan adanya hubungan antara unsur-unsur dalam keluarga. Hubungan yang terjadi di dalam sebuah keluarga kehendaknya menjadi hubungan yang harmonis, aman, tentram, sejuk da nyaman, penuh rasa kasih sayang, sehingga keluarga tersebut mendapatkan ketenangan dan ketentraman.

Dalam hidup berkeluarga sangat diharapkan sebagai oaring tua supaya memelihara keharmonisan hubungan suami isri, karena sebutan suami istri dalam Al-Qur'an diungkapkan Allah SWT, dengan kata "azwaj" kata itu secara harfiah berarti pasangan atau belahan" misalnya sebuah biji kacang yang terdiri atas dua belahan, maka masing-masing belahan itu disebut zauj (pasangan dari yang lain) hal itu berarti bahwa istri adalah pasangan atau belahan dari suaminya, begitu pula sebaliknya, masing-masing dapat berfungsi sebagai penyejuk jiwa dan raga bagi yang lain. Allah SWT berfirman dalam surat Al-baqarah : 187.

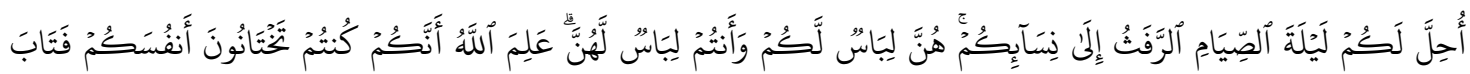

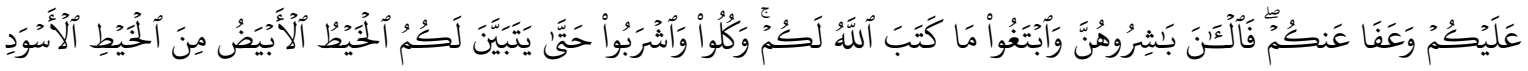

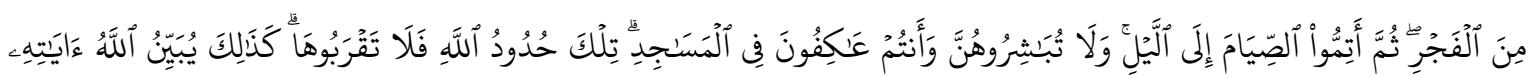

$$
\begin{aligned}
& \text { لِلنَّاسِ لَعَلََهُمْ يَتَقُونَن }
\end{aligned}
$$

Artinya: "Mereka itu adalah pakaian bagimu dan kamu pun adalah pakaian bagi mereka.

Dari ayat itu dapat dipahami, bahwa istri itu adalah pakaian bagi suaminya dan suami adalah pakaian bagi istrinya, pakaian dapat dipakai sesuai fungsinya, Adalah sebagai penutup aurat suami atau istri 
http://jurnaltarbiyah.uinsu.ac.id/index.php/raudhah e-mail: jurnalraudhah@uinsu.ac.id

p-ISSN: 2338-2163

e-ISSN: $2716-2435$

untuk saling menjaga citra kehidupannya. Pakaian termasuk perhiasan. Kegagahan dan kecantikan seseorang memang tidak anggun bila tidak ada lain jenis disampingnya.

Keluarga bisa menjadi teladan harus dicontohkan dari ayah dan ibu, terutama sebelum lahirnya anak, ayah dan ibu mesti sudah benar-benar siap membimbing anak-anak dan mempersiapkan diri untuk menjadi teladan positif bagi anak-anaknya atau keturunannya dikemudian hari nanti. (Kadar M. Yusuf, Tafsir Tarbawi Jakarta, 2013 : 153)

Di dalam al-Qur'an surah at Tahrim ayat 6 Allah SWT berfirman:

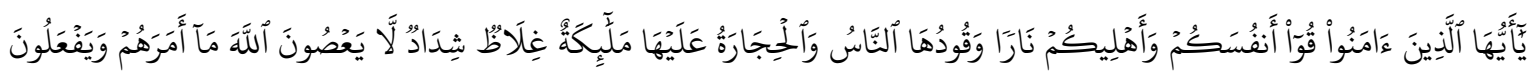
مَا يُوْْمَرونَنَ

Artinya: "Wahai orang-orang yang beriman! Peliharalah dirimu dan keluargamu dari api neraka...."

Secara tegas dan jelas ayat tersebut diatas mengingatkan kepada semua orang-orang mukmin agar mendidik diri dan keluarganya kejalan yang benar agar terhindar dari siksa api neraka. Ayat tersebut mengandung perintah menjaga, yaitu "Qu" (jagalah). Perintah menjaga diri dan keluarga dari neraka berkonotasi terhadap perintah mendidik atau membimbing. Sebab didikan dan bimbingan yang dapat membuat diri dan keluarga konsisten dalam kebenaran, dimana konsisten dalam kebenaran itu membuat orang terhindar dari siksa neraka. Oleh karena itu, para orang tua berkewajiban mengajarkan kebaikan, memberi contoh teladan dalam keluarga serta menanamkan ajaran agama kepada anak-anak dalam keluarga. Menyuruh mereka berbuat kebajikan dan menjauhkan kemungkaran serta memberikan contoh teladan. (Kadar M. Yusuf. Tafsir Tarbawi, 2013 $: 153)$.

Pembentukan karakter ini sangat cocok jika diimplementasikan pada anak dari sejak dini ketika anak masih dalam pantauan lingkungan keluarga seperti di dalam rumah. Pendidikan karakter merupakan salah satu cara membentuk karakter anak pada usia dini. Sedangkan rumah merupakan wadah untuk mengsukseskan kegiatan pembentukan yang bertujuan untuk membentukan karakter anak. Oleh karena itu, dalam melakukan proses pe pendidik dapat menggunakan berbagai media dan kegiatan yang dapat digunakan ketika pendidikan berlangsung dan pelaksaan kegiatan seperti memberikan contoh-contoh kegiatan sehari-hari yang dapat dijadikan tauladan bagi anak.( Muslich, 2020) 
http://jurnaltarbiyah.uinsu.ac.id/index.php/raudhah

e-mail: jurnalraudhah@uinsu.ac.id

p-ISSN: 2338-2163

e-ISSN: $2716-2435$

\section{B. METODE PENELITIAN}

Metode dan jenis pengumpulan data dalam penelitian ini adalah studi pustaka (Library Reseach) dengan mengumpulkan buku-buku, jurnal yang relevan, dan hasil penelitian terdahulu yang mendukung tema penelitian, diantaranya literature tentang etika pergaulan dalam keluarga muslim proses penelitian ini dimulai dengan tahapan sebagai berikut: mengidentifikasi dan menemukan informasi yang relevan dengan tema penjaminan mutu, kemudian menganalisis hasil temuan dan kemudian mengembangkan dan mengekspresikan menjadi temuan baru terkait dengan etika pergaulan dalam keluarga muslim.

\section{HASIL TEMUAN DAN PEMBAHASAN}

\section{Sikap Orang Tua Terhadap Anak.}

Orang Tua (Ayah dan Ibu) hendaknya selalu memberikan contoh dan suri tauladan, baik moral atau akhlak dan watak harus menunjukkan pribadi muslim pada umumnya. Jika ada pepatah mengatakan “ jika orang tua kencing berdiri, maka anak akan kencing berlari”. Sehingga apabila orang tua menunjukkan sikap dan watak yang kurang terpuji, maka anak akan memiliki sifat yang lebih buruk lagi. Pepatah orang jawa mengatakan. "Kacang ora ninggal lanjaran". Yang artinya : "sifat yang dimiliki oleh induknya, akan menurun kepada anaknya”. (Maimunah Hasan, Rumah Tangga Muslim, Yogyakarta, 2000 : 71).

Pepatah-pepatah tersebut jika dikaji secara filosofi tidak bertentangan dengan ajaran Islam. Untuk itu ajaran Islam menganjurkan orang tua dituntut untuk senantiasa bersikap dan berbuat sesuai dengan garis-garis yang ditetapkan Allah dan Rasulnya. Dengan demikian diharapkan setiap anggota keluarga memiliki sifat dan budi pekerti yang luhur yang sangat diperlukan dalam kehidupan berkeluarga dan bermasyarakat.( Maimunah Hasan : 72).

Dalam hal ini orang tua perlu menyadari akan kewajibannya masing-masing. Orang tua yang senantiasa melaksanakan kewajibannya dengan baik, sudah tentu secara langsung maupun tidak langsung telah mendidik putra putrinya untuk bertanggung jawab dalam menjalankan hidup sebagai khalifah di dunia ini. Orang tua berkewajiban untuk memberikan bimbingan dan contoh konkrit berupa keteladanan kepada anak bagaimana seseorang harus melaksanakan ajaran agama dalam kehidupan keluarga dan masyarakat agar mereka dapat hidup selamat dan hidup sejahtera. Kewajiban tersebut seperti, sudah penulis sebutkan dalam Al-Qur'an surat AtTahrim ayat enam terdahulu. 
http://jurnaltarbiyah.uinsu.ac.id/index.php/raudhah

e-mail: jurnalraudhah@uinsu.ac.id

p-ISSN: 2338-2163

e-ISSN: 2716-2435

Bagi suami istri agama merupakan benteng yang kokoh terhadap berbagai ancaman yang dapat merapuhkan dan meruntuhkan kehidupan keluarga. Dalam hal ini agama berperan sebagai sumber pendorong dan tempat untuk mengembalikan dan memecahkan masalah oleh karena itu perlu bagi suami istri memegang dan melaksanakan ajaran agama dengan sebaik-baiknya dalam arti mau dan mampu melaksanakan kehidupan beragama dalam kehidupan keluarga baik dalam keadaan suka maupun duka. Upaya kearah itu dapat dilaksanakan selama dengan cara gemar memperoleh ilmu agama juga dapat dilakukan dengan cara suka mendekatkan diri kepada Allah SWT. Allah SWT berfirman.

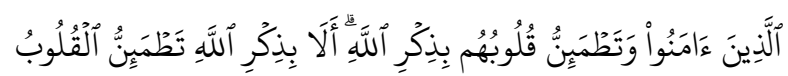

Artinya: "Hai orang-orang yang beriman, hati mereka menjadi tentram dengan mengingat Allah. Ingatlah hanya dengan mengingat Allah hati akan menjadi tentram (Q.S. Ar-Ra'du : 28)

Ketenangan jiwa sangatlah penting dalam kehidupan berkeluarga, karena itulah harus diperbanyak mengingat Allah SWT. Kemudian kewajiban seorang ayah terhadap anak-anaknya. Rasulullah SAW bersabda yang bermaksud: "Kewajiban seorang ayah terhadap anaknya, ialah memberi dia nama yang baik, mengajari dia kesopanan yang baik, mengajari dia menulis, berenang dan memanah, dan jangan beri dia makan melainkan barang yang baik dan nikahkan dia apabila dia sudah baligh.” (HR. Hakim).

Adapun yang dimaksud dengan mengajari kesopanan yang baik, mengajar menulis dan sebagainya adalah memberikan prinsip-prinsip pendidikan anak sesuai hadits tersebut, diantaranya adalah: Pertama, menanamkan keimanan kepada Allah secara murni, yaitu meng-Esakan Allah yang tidak bercampur dengan kesyirikan. Kedua, menanamkan rasa wajib berbuat baik dan bersikap hormat kepada orang tua, meskipun berbeda keyakinan beragama. Ketiga, menanamkan rasa wajib meng-Esakan Allah dan menyembah-Nya, karena Allah adalah Tuhan yang wajib disembah. Keempat, menanamkan rasa wajib bersikap hormat kepada sesama, tidak congkak, tidak sombong, baik dalam ucapan maupun perbuatan.

Berbicara soal konsep rumah tangga tidak dapat dipisahkan dengan pembicaraan soal konsep ibu rumah tangga, bahkan ibu dalam rumah tangga merupakan soko guru, tiang penentu tegak tidaknya isi rumah tangga tersebut. Isi rumah tangga itu bukan sekedar benda-benda mati tetapi termasuk juga anak-anak, amanah suami, dan lain-lain. Sehingga membicarakan soal konsep tentang ibu rumah tangga sebenarnya membicarakan sesuatu yang amat asasi. Karena itu konsep tersebut harus diupayakan seoptimal mungkin untuk dilaksanakan agar memperoleh manfaat yang dicitacitakan oleh seluruh anggota rumah tangga, yang mana cita-cita keluarga muslim itu tidak hanya 
http://jurnaltarbiyah.uinsu.ac.id/index.php/raudhah

e-mail: jurnalraudhah@uinsu.ac.id

p-ISSN: 2338-2163

e-ISSN: $2716-2435$

berorientasi duniawi, melainkan jauh lebih tinggi dari pada itu, yaitu cita-cita ukhrawi dan surgawi. (Maimunah Hasan . 2000 : 77).

Menurut Kadar M. Yusuf dalam Tafsir tarbawi, 2013 : 152-153. Etika pergaulan dalam keluarga itu dimulai dari istri dan suami, mereka mesti saling menghormati dan melaksanakan kewajiban mereka masing-masing. Selain itu, mereka juga dituntut agar selalu berbenah diri untuk menjadi insan yang shaleh dam bertakwa kepada Allah SWT. Kondisi ini merupakan tonggak utama dalam pendidikan dalam keluarga. Kebiasaan orang tua dalam keharmonisan dan ketaatan kepada Allah SWT dapat mempengaruhi anak-anak sebagai peserta didik dalam keluarga tersebut. Para istri atau ibu memainkan peranan penting dalam pendidikan anak. Ibu adalah sekolah pertama bagi anakanak dalam suatu keluarga. Perilaku, tutur sapa, dan kebiasaan-kebiasaan yang dilakukan seorang ibu akan selalu menjadi rujukan atau ditiru oleh anak, demikian pula sikap dan perilaku ayah. Maka oleh sebab itu, pendidikan dalam suatu keluarga meski dimulai dari ayah dan ibu. Sebelum terjadinya perkawinan, atau paling tidak sebelum lahirnya anak, ayah dan ibu mesti sudah benar-benar siap membimbing anak-anak dan mempersiapkan diri untuk menjadi teladan positif bagi anak-anak.

Secara tegas dalam ayat surah At-Tahrim terdahulu diatas mengingatkan kepada semua orang mukmin agar mendidik diri dan keluarganya kejalan yang benar agar terhindar dari neraka. Ayat tersebut mengandung perintah menjaga (jagalah). Perintah menjaga diri dan keluarga dari neraka berkonotasi terhadap perintah mendidik atau mebimbing. Sebab didikan dan bimbingan yang dapat membuat diri dan keluarga konsisten dalam kebenaran, dimana konsisten dalam kebenaran itu membuat orang terhindar dari siksa neraka. Oleh karena itu, para orang tua berkewajiban mengajarkan kebaikan dan ajaran agama kepada anak-anak, menyuruh mereka berbuat kebajikan dan menjauhkan kemungkaran dengan membiasakan mereka dalam kebenaran atau kebaikan tersebut, serta memberikan contoh teladan yang baik. (Kadar M. Yusuf, 2013 : 153).

Berikutnya etika orang tua juga terhadap anak-anaknya yang berhubungan dengan akhlak yaitu: Pertama, biasakanlah anak untuk menggunakan tangan kanan dalam mengambil, memberi, makan dan minum, menulis dan menerima tamu, serta mengajarkannya untuk selalu memulai setiap pekerjaan dengan basmalah. Terutama untuk makan dan minum dan harus dilakukan dengan duduk serta diakhiri dengan membaca hamdalah. Kedua, membiasakan anak untuk selalu menjaga kebersihan, memotong kukunya, mencuci kedua tangannya sebelum dan sesudah makan, dan mengajarinya untuk bersuci ketika buang air kecil maupun air besar, sehingga tidak membuat najis pakaiannya dan ketika shalatnya menjadi sah. Ketiga, bertambah sabar dan lembut dalam memberi nasehat kepada mereka dengan cara diam-diam, tidak membuka kesalahan mereka di depan umum, jika mereka tetap tidak mau patuh terhadap nasehat, maka kita tetap sabar dan doakan dengan 
http://jurnaltarbiyah.uinsu.ac.id/index.php/raudhah

e-mail: jurnalraudhah@uinsu.ac.id

p-ISSN: 2338-2163

e-ISSN: 2716-2435

kebaikan. Keempat, membiasakan mereka untuk tidak membuang sampah dan kotoran di tengah jalan dan menghilangkan hal-hal yang menyebabkan mereka bisa sakit. Kelima, waspada terhadap persahabatan mereka dengan kawan-kawan yang kurang baik akhlaknya, mengawasi mereka, dan melarang mereka untuk duduk-duduk dipinggir jalan. Keenam, memberi salam kepada orang-orang yang dirumah, dijalan, maupun di dalam kelas (Maimunah Hasan. 2000 : 82-83).

\section{Sikap anak terhadap orang tua}

Berapa jasa orang tua terhadap putra putrinya sangat sulit untuk dihitung. Dengan susah payah kedua orang tua menjaga putra putrinya. Dibawah guyuran hujan, teriknya matahari, bermandikan keringat, mencari nafkah guna menghidupi putra-putrinya. Mereka merasa bimbang dan cemas disaat putra-putrinya sakit. Lantaran itulah kiranya seorang anak wajib untuk berbuat baik kepada kedua orang tua, apakah itu dengan perkataan, dengan sikap dan perangai, dengan tenaga atau dengan apa saja yang dinamakan baik. Allah SWT berfirman:

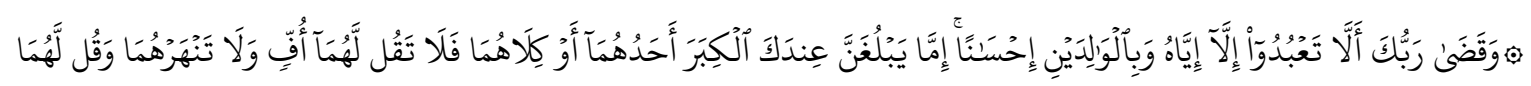

قَوْلَ كَرِيَمَا

Artinya: "Dan Tuhanmu telah memerintahkan supaya kamu jangan menyembah selain Dia dan hendaklah kamu berbuat baik pada ibu bapakmu dengan sebaik-baiknya. Jika salah seorang di antara keduanya atau kedua-duanya sampai berumur lanjut dalam pemeliharaanmu, maka sekalikali janganlah kamu mengatakan kepada keduanya perkataan "ah" dan janganlah kamu membentak mereka dan ucapkanlah kepada mereka perkataan yang mulia.”. (Q.S. Bani Israil : 23).

Berbakti dan berbuat baik kepada orang tua, mengasih sayangi, mendoakan, taat dan patuh kepadanya, menunaikan kewajiban terhadapnya dan melakukan hal-hal yang membuat kedua orang tua ridha serta meninggalkan sesuatu yang membuatnya murka, adalah kewajiban yang harus dilaksanakan setiap anak. Semua itu di laksanakan setiap anak. Semua itu disebut dengan istilah "Birrul walidain". Kemudian berbakti kepada orang tua itu hukumnya Fardhu 'ain atau kewajiban yang harus dilakukan oleh setiap diri umat muslim (Muhammad Nur Abd hafiz, Manhaj atTarbiyyah an-Nabawiyah Li at-Tifli, Terjemah kuswandani dkk, Bandung Al-Bayan, 1997 : 268).

Oleh karena itu Allah SWT, telah memberikan peringatan yang tegas kepada anak agar memperhatikan hak kedua orang tua, melebihi perhatiannya kepada orang lain. Sebab konsekuensi yang akan ditimbulkan dan mereka rasakan bila melalaikan mereka sangat besar. Aktivitas apapun yang bisa menggelisahkan hati dan menyinggung perasaan keduanya (atau salah satunya) tergolong perbuatan maksiat. 
http://jurnaltarbiyah.uinsu.ac.id/index.php/raudhah

e-mail: jurnalraudhah@uinsu.ac.id

p-ISSN: 2338-2163

e-ISSN: 2716-2435

Berdasarkan ayat diatas, kita mengerti bahwa taat dan patuh kepada perintah orang tua merupakan salah satu kewajiban yang sangat utama dalam mendekatkan diri kepada Allah. Yang berarti pula durhaka kepada orang tua adalah salah satu dari perbuatan dosa besar. Orang tua adalah perantara bagi kehadiran kita dimuka bumi ini, yang pertama kali mengasuh, membimbing dan mengajar kita. Mereka penuh keihklasan merawat, mengasuh, mengajar dan mendidiknya. Rasa sabar dan tabah senantiasa menghiasi dirinya.

Selanjutnya, Ahmad Musthafa al-Maraghi menjelaskan dalam ayat tersebut, orang tua itulah yang belas kasihan kepada anaknya, dan telah bersusah payah dalam memberikan kebaikan kepadanya, dan menghindarkan dari bahaya. Oleh karena itu, wajiblah hal itu diberi imbalan dengan berbuat baik dan syukur pada keduanya. (Ahmad Musthafa al-Maraghi, Juz 15 : 33). Anak adalah belahan jiwa dari orang tua, dan kedua orang tua telah memberi kenikmatan pada anak, ketika anak itu sedang dalam keadaan lemah dan tidak berdaya sedikitpun. Oleh karena itu wajib hal itu dibalas dengan rasa syukur ketika orang tua itu telah lanjut usia. Dalam surah Bani Israil ayat 23 tersebut diatas al-Maraghi menyimpulkan, jangan kamu jengkel terhadap sesuatu yang kamu lihat dilakukan oleh salah satu dari orang tua atau oleh keduanya yang mungkin dapat menyakitkan hati orang lain tetapi bersabarlah menghadapi semua itu. Janganlah kamu menyusahkan keduanya dengan suatu perkataan yang membuat mereka tersinggung. Ucapkanlah ucapan yang baik kepada kedua orang tua dan perkataan yang manis, dibarengi dengan rasa hormat dan mengagungkan, sesuai dengan kesopanan yang baik, dan sesuai dengan tuntunan kepribadian yang luhur. Bersikaplah kepada orang tua dengan sikap "tawadhu" (rendah hati) dan taatlah kepada mereka berdua dalam segala yang diperintahkan terhadapmu selama tidak bermaksiat kepada Allah. (Ahmad Musthafa al-Maraghi, juz :15: 35$)$.

Seorang anak harus ingat, bahwa kedua orang tua memelihara putra-putrinya dengan menanggung beberapa kesengsaraan dan beberapa penderitaan. Mereka melaksanakan bukan karena terpaksa tidak pernah merasa jenuh atau bosan. Tetapi semua itu dilaksanakan dengan rasa suka dan riang gembira, dengan tulus dan ikhlas, dengan cinta dan kasih sayang. Oleh sebab itu pantaslah kiranya, jika seorang anak berlaku sopan serta merendahkan diri kepada kedua orang tua, dengan tidak terpaksa dan tanpa pamrih. Allah SWT berfirman:

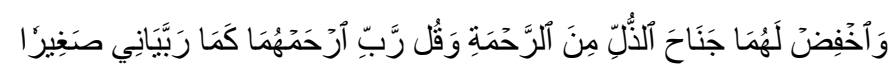

Artinya: "Dan rendahkanlah dirimu terhadap mereka berdua dengan penuh kasih sayang dan ucapkanlah, wahai Tuhanku, kasihanilah mereka berduanya, sebagaimana mereka berdua telah mendidik aku waktu kecil.” (Q.S. Bani Israil : 24). 
http://jurnaltarbiyah.uinsu.ac.id/index.php/raudhah

e-mail: jurnalraudhah@uinsu.ac.id

p-ISSN: 2338-2163

e-ISSN: $2716-2435$

Hendaknya seorang anak selalu menyenangkan hati kedua orang tuanya seberapapun besarnya, baik itu dengan perkataan, dengan sikap dan perangai yang baik, dan jangan sekali-kali menyebabkan mereka itu murka atau benci atas putra-putrinya. Rasulullah SAW pernah bersabda seperti dikutip oleh. (Hamudah Hasan : 87).

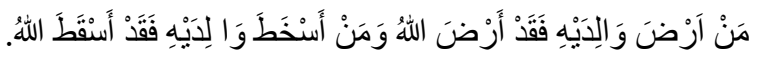

Artinya: "Barang siapa menyukakan kedua orang tuanya (ibu dan ayahnya), sesungguhnya ia telah menyukakan Allah, dan barang siapa membikin ibu dan ayahnya marah sesungguhnya ia telah membikin Allah murka”. (HR. Bukhari).

Jika seorang anak ingin berhasil di dunia dan di akhirat, maka hendaknya mengerjakan beberapa pesan berikut ini: Pertama, berbicara dengan orang tua dengan sopan santun, jangan mengucapkan "ah" kepada mereka, jangan menghardik mereka dan berkatalah kepada mereka dengan ucapan yang baik. Kedua, taatilah mereka selama tidak menyuruh dalam maksiat, karena tidak ada ketaatan pada makhluk yang bermaksiat kepada Allah. Ketiga, berlemah lembutlah kepada kedua orang tua, jangan bermuka masam didepannya, dan jangan memelototi mereka dengan marah. Keempat, jaga nama baik, kehormatan dan harta benda kedua orang tua. Dan jangan mengambil sesuatu apapun tanpa seizin keduanya. Kelima, lakukanlah hal-hal yang meringankan keduanya meski tanpa perintah seperti berhemat, membelikan beberapa keperluan dan bersungguh-sungguh dalam mencari ilmu pengetahuan. Keenam, segera penuhi panggilan mereka dengan wajah tersenyum sambil berkata: ada apa bu, atau ada apa ayah. Ketujuh, hormati teman dan sanak kerabat mereka ketika mereka masih hidup dan sesudah almarhum atau almarhumah. Kedelapan, jangan bantah mereka dan jangan persalahkan, tapi usahakan dengan sopan untuk dapat menjelaskan dengan benar. Kesembilan, jangan membantah perintah mereka, jangan mengeraskan suara kepada mereka, dengarkanlah pembicaraanya, bersopan santunlah kepada mereka dan jangan menggangu saudara yang berlaku hormat kepada kedua orang tua. Kesepuluh, jangan pergi jika mereka belum memberi izin meski untuk urusan penting, jika terpaksa harus pergi maka mintalah maaf kepada keduanya dan jangan sampai memutuskan hubungan silaturrahim dalam bentuk apapun. (Maimunah Hasan : 88-93).

\section{Sikap anak terhadap ibunya}

Kiranya tidak ada seseorang manusia di dunia ini, yang sudah menanggung sengsara, beban penderitaan, susah payah, menahan perut, menahan mata, menahan pedih dan sebagainya kecuali seorang ibu yang sedang mengandung, melahirkan, menyusui dan membesarkan putra-putrinya. Besarnya kesusahan yang telah dirasakan oleh seorang ibu, dari masa mengandung hingga 
http://jurnaltarbiyah.uinsu.ac.id/index.php/raudhah

e-mail: jurnalraudhah@uinsu.ac.id

p-ISSN: 2338-2163

e-ISSN: $2716-2435$

menjadikan putra-putrinya hidup mandiri, tidak bisa dilukiskan ataupun diceritakan dengan katakata mutiara apalagi dipermudah-mudahkan.

Untuk itu tepatlah jika Allah menganjurkan seorang anak untuk berbakti kepada ibunya, melalui firman-Nya dalam Al-Qur'an:

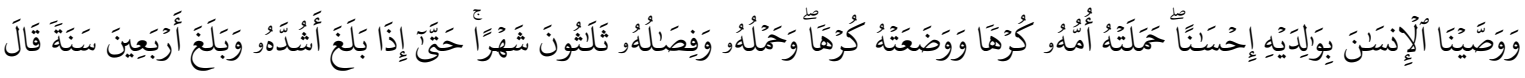

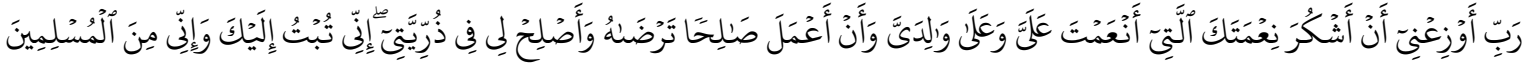

Artinya: "Kami telah mewajibkan manusia berbuat baik kepada kedua orang tuanya. Ibunya telah mengandung dia dengan susah payah dan melahirkan dia dengan susah payah pula”. (Q.S AlAhqaf : 15).

Demikian besar jasa ibu terhadap putra-putrinya dan begitu tinggi derajatnya, baik ditinjau dari sisi agama maupun secara logika. Sehingga sudah selayaknya apabila seorang anak menunjukkan rasa terima kasih kepada ibunya dengan jalan memberikan suatu kesenangan maupun dengan jalan hormat dan patuh kepadanya. Hendaknya seorang anak harus ingat, bahwa seorang ibu memelihara putra-putrinya dengan hati yang tulus dan ikhlas, tanpa adanya unsur paksaan sedikitpun. Akan tetapi ternyata masih ada seorang anak yang merawat ibunya dengan perasaan terpaksa, dengan merasa berat, bahkan kadang-kadang menunjukkan muka yang payah dan sikap yang tidak senang ataupun marah.

Tidak menutup kemungkinan akan dijumpai di dunia ini seorang anak yang merawat ibunya, antara ucapannya bertolak belakang dengan kata hatinya: "Baiklah aku rawat ibu dengan sungguhsungguh karena tidak lama lagi ia akan meninggal". Sikap seperti itu seharusnya dihindari. Dalam kondisi apapun hendaknya senantiasa seorang anak selalu dekat dengan ibunya. Jadikanlah seorang ibu itu menjadi seorang sahabat sejati yang lebih dari yang lain. (Maimunah Hasan : 95-97). Dalam skala prioritas antara ayah dan ibu, yang menempati peringkat lebih istemewa untuk diperhatikan adalah ibu. Pengorbanan beliau tidak bisa dibalas dengan bentuk apapun, apalagi hanya terima kasih. Ibulah yang telah banyak menderita, mengandung anak, merasakan sakitnya melahirkan, menyusui bahkan tidak jarang harus berjaga sepanjang malam demi anaknya. Karena itu ibu memiliki hak yang lebih banyak dibandingkan ayah. Oleh karena itu Allah meletakkan surga dibawah telapak kaki ibu. Ibu adalah didahulukan atas ayah dalam kebaikan. Seperti sabda Rasulullah yang dikutip oleh Abdul Hakam Ash-Sha'idi dalam buku menuju keluarga sakinah, (Jakarta. 2001: 175). "Abu Hurairah ra mengatakan bahwa seorang pria datang kepada Rasulullah dan berkata," Wahai Rasulullah, siapalah orang yang paling berhak aku berbakti dalam pergaulan? "Beliau menjawab, Ibumu, ia bertanya lagi, lalu siapa? Beliau menjawab Ibumu, lalu siapa? Beliau menjawab lagi 
http://jurnaltarbiyah.uinsu.ac.id/index.php/raudhah

e-mail: jurnalraudhah@uinsu.ac.id

p-ISSN: 2338-2163

e-ISSN: 2716-2435

Ibumu, kemudian orang itu bertanya lagi "lalu siapa? Rasulullah menjawab, “Ayahmu”. ( HR. Muttafaqun 'alaihi).

\section{Sikap anak terhadap ayahnya}

Sesuai dengan ajaran Islam bahwa kewajiban anak terhadap ibunya lebih berat dari pada kewajiban terhadap ayahnya. Sungguh pun demikian, agama Islam tetap mengajarkan bahwa seorang anak tidak boleh melupakan apalagi memutuskan tali kasih sayang dengan ayahnya. Rasulullah bersabda seperti dikutip oleh Maimunah Hasan (2000: 101).

$$
\text { رِضَ اللهِ فِنْ رِضَ الْوَالِلِ وَسُخْطُ اللهِ فِي سُخْطِ الْوَالِلِ. }
$$

Artinya: "Keridhaan Allah tergantung dengan keridhaan orang tua, dan kemurkaan Allah tergantung dengan kemurkaan orang tua". (HR. Tirmidzi).

Sedangkan menurut Abdul Nashih Ulwan dalam buku, Tarbiyatul Aulad (Terjemah) 2020 : 223) ada banyak riwayat dari para "salafus saleh" mengenai komitmen mereka dalam melaksanakan adab-adab terhadap ayah mereka antara lain: Pertama, seorang penulis Majma'uz Zawa'id, menyebutkan bahwa Abu Ghasan adh-Dhabi menuturkan. "suatu hari aku berjalan bersama ayahku dihari yang sangat terik, lalu aku bertemu Abu Hurairah. Iya bertanya, siapa ini ? Aku menjawab, ini ayahku, "ia berkata, jangan engkau berjalan di depan ayahmu, namun berjalannya dibelakangnya atau disampingnya. Jangan biarkan ada penghalang diantara kamu dan dia. Jangan engkau memakan tulang (yang sebagian dagingnya sudah ia makan) dihadapan ayahmu sedang ia melihatnya, karena boleh jadi ia menginginkannya. Kedua, diriwayatkan di dalam kitab Uyun al-Ahbar bahwa Khalifah al-Makmun telah berkata aku belum pernah melihat orang yang lebih berbakti kepada ayahnya dari pada al-Fadhl bin Yahya. Diantara kebaikannya adalah disaat ia dan ayahnya ditahan dipenjara. Yahya (ayah al-Fadhl) ini hanya dapat berwudhu dengan air hangat, padahal petugas penjara melarang mereka memasukkan kayu bakar di malam yang dingin (untuk merebus air). Kemudian ketika ayahnya sedang tidur. Al-Fadhl mengambil botol minyak untuk menghangatkan air, ia mengisi botol itu dengan air dan mendekatkannya ke api lampu. Ia terus lakukan itu hingga waktu subuh. Semua ini adalah wujud baktinya agar ayahnya dapat berwudhu dengan air hangat. Ketiga, suatu saaat Shalih bin al-Abbas hadir pada majelis Khalifah al-Manshur. Ia berbicara kepada khalifah dan berulang kali mengatakan "Semoga Allah merahmati ayahku (Ayahku Rahimahullah) lalu ada seorang yang bernama Rabi' berkata, "jangan engkau terlalu banyak mengatakan semoga Allah merahmati ayahku, dihadapan Amirul Mukminin, tapi Shaleh berkata "Aku tidak akan mencelamu, karena kamu tidak pernah merasakan manisnya (cinta) Ayah, al-Manshur pun tersenyum dan berkata, "inilah balasan bagi orang yang menentang Bani Hasyim. Keempat, Ibnu Hibban meriwayatkan bahwa ada seorang pria menemui Abu darda' lalu berkata "Ayahku selalu 
http://jurnaltarbiyah.uinsu.ac.id/index.php/raudhah

e-mail: jurnalraudhah@uinsu.ac.id

p-ISSN: 2338-2163

e-ISSN: 2716-2435

bersamaku hingga ia menikahkanku sampai sekarang ia menyuruhku untuk menceraikan istriku". Abu Darda' berkata 'aku tidak menyuruhmu untuk mendurhakai kedua orang tuamu, juga tidak menyuruhmu untuk menceraikan istrimu. Namun jika kamu mau, aku akan memberikan sebuah hadits yang pernah ku dengar dari Rasulullah SAW, aku mendengar beliau bersabda "seorang ayah dalah pintu surga yang paling tengah, jagalah pintu itu, tapi jika kamu mau tinggalkanlah”. Kelima, dari Aisyah ra. Ia berkata suatu hari ada seorang pria menemui Rasulullah bersama seorang yang sudah tua. Rasulullah bertanya, hai saudaraku, siapa orang yang bersamamu ini ? Orang itu menjawab "Ayahku! Ya Rasulullah, kemudian Rasul bersabda. "jangan engkau berjalan didepannya, jangan duduk sebelum ia duduk, jangan memanggilnya dengan namanya dan jangan melecehkannya".

\section{Kewajiban Anak terhadap orang tua yang sudah meninggal}

Seorang anak tidak hanya wajib berbakti kepada kedua orang tua selama mereka masih hidup, akan tetapi setelah almarhum atau almarhumah, juga tetap harus berbuat baik kepada kedua orang tua. Adapun bagaimana caranya untuk berbuat baik kepada kedua orang tua yang sudah meninggal dunia, tidak ada cara lain selain melalui ajaran agama, yaitu shalatkanlah mereka, mintakan ampunan dosa mereka, sempurnakan janji mereka, muliakan sahabat dan keluarga yang bergantung kepada mereka. Karena ada hadits Rasulullah yang dikutip oleh (Moh Rifa'I dalam buku 300 hadis bekal dakwah, Semarang, 1980 : 102).

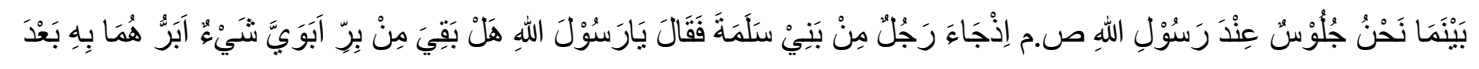

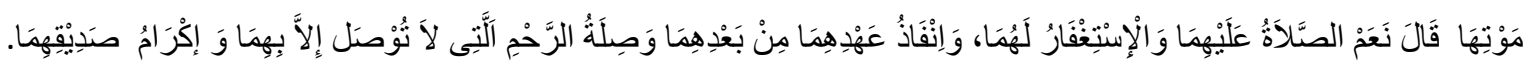
Artinya: "Pada waktu saya duduk beserta Rasulullah SAW, tiba-tiba ada seorang laki-laki dari Bani Salamah datang, lalu bertanya, wahai Rasulullah, apakah masih dapat saya lakukan untuk berbakti kepada dua ibu bapakkku sesudah meninggalnya ? Nabi menjawab, ada, yaitu berdoa dan beristigfar (memohonkan maghfirah ampunan) untuknya, dan memenuhi segala wasiatnya dan segala janji-janjinya dan menghubungkan silaturrahim yang harus dihubungi lantarannya. Selain itu menghormati dan memuliakan teman-temannya dahulu". (HR Abu Daud, Ibn Majah dan Ibn Hiban).

\section{Hormat kepada saudara tua dan menjalankan hak saudara (Arham)}

Sesudah kedua orang tua meninggal dunia, tidak ada seorangpun manusia yang lebih dekat, lebih cinta, lebih berhak atas diri seseorang kecuali saudara yang lebih tua, baik pria maupun wanita. Untuk itu agama tetap mengajarkan untuk berlaku sopan dan hormat kepada saudara yang lebih tua 
http://jurnaltarbiyah.uinsu.ac.id/index.php/raudhah

e-mail: jurnalraudhah@uinsu.ac.id

p-ISSN: 2338-2163

e-ISSN: 2716-2435

bermusyawarah dengan mereka dalam hal yang dianggap penting. Rasulullah bersabda seperti dikutip oleh (Maimunah Hasan. 2000 : 111-112)

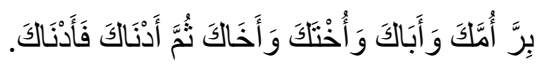

Artinya: "Buatlah kebaikan kepada ibumu dan ayahmu dan saudara perempuan serta saudara lakilakimu, sesudah itu keluarga yang lebih dekat, lantas yang lebih dekat”. (HR. Nasa'i).

Meskipun derajat saudara yang lebih tua itu ditinjau dari sudut agama Islam hampir sama dengan kedua orang tua akan tetapi dalam pergaulan hidup sehari-hari hanya sedikit hal ini dijumpai, hanya terbatas golongan tertentu saja yang mampu memahami akan ajaran Rasul tersebut. Bahkan banyak dijumpai masyarakat, umumnya masyarakat dengan idola pendidikan ala barat, tidak kenal dengan saudara atau family ayah dan ibu. Kondisi seperti ini merupakan buah dari hasil pendidikan barat, yang mengharuskan tiap-tiap orang harus berdiri sendiri, jangan bergantung kepada orang lain. Sikap mesti berdiri sendiri itu memang baik dan juga tetap dianjurkan oleh ajaran agama, akan tetapi bukan berarti berdiri sendiri, itu lantas lupa atau tidak tahu kepada sanak saudara, atau family. Apalagi berlaku tidak sopan kepada orang tua dan saudara tua, sangat dilarang oleh ajaran agama Islam. Semoga rumah tangga muslim terhindar dari sifat yang demikian itu. ( Maimunah Hasan, $2000: 112)$.

Menurut (Abdullah Nashih Ulwan, 2020 : 227) saudara (arham) adalah orang yang memiliki garis keturunan atau kekerabatan urutannya adalah: ayah dan ibu, kakek dan nenek, saudara dan saudari kandungnya, paman dan bibi dari ayah, keponakan dari saudari kandung paman dan bibi dari ibu. Kemudian menyusul kerabat dan keluarga lainnya. Mereka semua disebut saudara (arham) karena ada dua sebab. Pertama, terbentuk dari kata "Rahm" dan nama ar-Rahman. Ini ditegaskan oleh Nabi SAW dalam sebuah hadits yang diriwayatkan oleh Abu Daud dan Tirmidzi dari Abdurrahman bin Auf ra. Bahwa ia mendengar Rasulullah SAW bersabda, “Allah Ta'ala berfirman, Aku adalah Allah, aku adalah ar-Rahman. Kubentuk nama-Nya dari nama-Ku, maka barang siapa yang menghubungkannya, maka aku akan berhubungan denganya. Siapa yang memutuskannya, maka aku akan putus dengannya".Jelaslah, pembentukan tersebut merupakan pembangkit rahmat, dan pendorong kasih sayang dan cinta kasih terhadap orang yang memiliki hubungan kekerabatan dan pertalian garis keturunan. Kedua, karena garis kekerabatan turun dari asalnya (garis keturunan) yang dijadikan pegangan oleh manusia. Inilah yang didukung Nabi SAW, dalam arahan-arahannya mulia bagi kewajiban menyambung persaudaraan dan memperingatkan untuk tidak memutuskannya. Jelaslah, bahwa yang menggerakkan rasa kekerabatan dari dalam jiwa dan membangkitkan kasih sayang adalah rasa persaudaraan yang tinggi. 
http://jurnaltarbiyah.uinsu.ac.id/index.php/raudhah e-mail: jurnalraudhah@uinsu.ac.id

p-ISSN: 2338-2163

e-ISSN: 2716-2435

Jika demikian para keluarga muslim setelah menjelaskan hak-hak ini harus giat membantu dengan sungguh-sungguh untuk membuka mata anaknya sejak masih muda untuk melihat hak-hak kerabat dan saudara. Agar mereka dapat tumbuh di dalam keterikatan dengan garis keturunan. Hingga bila ia sudah dewasa dan matang pikirannya, ia dapat menunaikan kewajiban untuk mengasihi dan berbuat baik kepada mereka, menghormati yang tua, menyayangi yang kecil, dan mencucurkan air mata atas musibah yang menimpa mereka, serta mengulurkan bantuan dan kebaikan saat mereka miskin atau ditimpa musibah. Ini tidak akan terjadi kecuali bila anak sudah terdidik dengan cara ini, dan terbiasa pada keutamaan dan kemuliaan.

Maka tidaklah aneh lagi jika saat kita membaca al-qur'an, kita akan menjumpai ayat-ayat yang mengajak untuk menghubungkan silaturrahim, dan memerintahkan untuk berbuat baik kepada kerabat dekat, berikut ini firman Allah diantaranya:

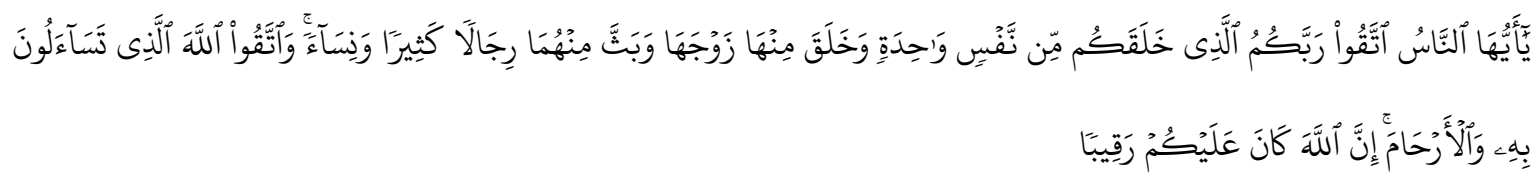

Artinya: "Dan bertakwalah kepada Allah yang dengan nama-Nya kamu saling meminta satu sama lain, dan (peliharalah) hubungan silaturrahim (kekeluargaan). Sesungguhnya Allah selalu menjaga dan mengawasi kamu”. (QS An-Nisa : 1).

\section{SIMPULAN}

Komponen utama dalam keluarga adalah orang tua. Mereka adalah orang tua. Mereka adalah orang yang paling berperan mempengaruhi peserta didik dikemudian hari, hal itu dimungkinkan karena merekalah yang paling awal bergaul dengan anaknya, paling dekat dalam berkomunikasi, dan paling banyak menyediakan waktu untuk anak terutama ketika ia masih kecil. Tidak sulit dipahami jika orang tua memiliki pengaruh yang besar dalam perkembangan anaknya. Sehubungan dengan ini, terdapat hadits yang dikutip oleh Bukhari Umar. Rasulullah SAW bersabda:

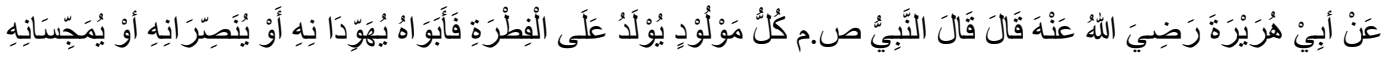

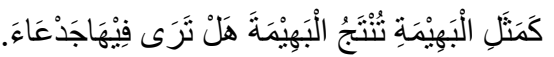

Artinya: : “Abu Hurairah r.a meriwayatkan bahwa Nabi SAW bersabda.” Setiap anak dilahirkan menurut fitrah (potensi beragama Islam). Selanjutnya, kedua orangtuanyalah yang membelokkanya menjadi Yahudi, Nasrani, atau Majusi bagaikan binatang melahirkan binatang, apakah kamu melihat kekurangan padanya?”. (HR. Al-Bukhari). 
http://jurnaltarbiyah.uinsu.ac.id/index.php/raudhah e-mail: jurnalraudhah@uinsu.ac.id

p-ISSN: 2338-2163

Kata "abawah" yang berarti kedua orang tua dalam hadits diatas tidak berarti menafikkan pengaruh pihak lain. Dalam kenyataanya masih banyak komponen lingkungan yang dapat mempengaruhinya, seperti suami istri, sudara, kakek, nenek, paman, bibi, dan seterusnya. Disebut kedua orang tua untuk mewakili lingkungan dapat dipahami karena dominasi peran dan pengaruh orang tua terhadap perkembangan anak.

\section{DAFTAR PUSTAKA}

Abdul Hakam Ash-Sha’idi, Menuju Keluarga Sakinah, Jakarta, 2001.

Abdullah Nashih Ulwan, Tarbiyatul Aulad (Terjemah Emiel Ahmad, Jakarta, 2020).

Ahmad Musthafa al-Maraghi, Tafsir al-Maraghi, juz 28 Mesir, 1974.

Al-Qur'anul Karim, (2009) Terjemah perkata, Departemen Agama, Jakarta.

Bukhari Umar, Hadis Tarbawi, Jakarta, 2012

Hammudah Abdu al-'Ati, The Family Structure in Islam, Terjemah Anshari Thaib, Keluarga Muslim Surabaya, 1984.

Kadar M. Yusuf, Tafsir Tarbawi, Jakarta, 2013

M. Quraish Shihab, Membumikan Al-Qur’an, Bandung, Mizan, 1984

Maimunah Hasan, Rumah Tangga Muslim, Yogyakarta, 2000

Muhammad Rifa'I, Tiga Ratus Hadis Bekal Dakwah, Semarang. 1980

Muhyiddin Abdul Hamid, Kegelisahan Rasulullah Mendenga

Muslich, Pendidikan Karakter: Menjawab Tantangan Krisis Multidimensional $\mathrm{r}$ Tangisan Anak, Yogyakarta, 2000. 